\title{
人口減少社会における配水管網の 再構成のあり方に関する検討
}

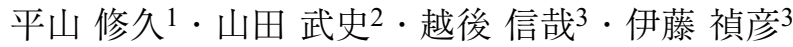 \\ 1正会員 名古屋大学減災連携研究センター（广464-8601 名古屋市千種区不老町） \\ hirayama.nagahisa@nagoya-u.jp \\ 2京都市上下水道局（７601-8004 京都市南区東九条東山王町 12 番地） \\ 3 正会員 京都大学大学院工学研究科（† 615-8540 京都市西京区京都大学桂）
}

\begin{abstract}
現在, 我が国の水道事業体は人口減少等による水需要の減少などを考慮して, 老朽化した施設更新を行 うことが求められており, 中長期的な視点から配水管網の再構築後のあり方について検討する必要がある. 本研究は, 濁水発生を予防するという管路の自己洗浄機能, 地震時に抢ける耐震機能, 抄よび配水管網の消 火機能の 3 つの観点から，管路の縮径と配水管網の一部に対して枝状化による配水管網の再構成による将 来の配水管網のあり方について, 神戸市を解析対象とした管網解析を行うことにより検討した。 その結果, 配水管網の縮径においては, 自己洗浄機能と耐震機能, 自己洗浄機能と消火機能がトレードオフ関係にあ ることを示しえた
\end{abstract}

Key Words: redesign of water distribution system, self cleaning function, fire protection, earthquake resilience, de-population society

\section{1. はじめに}

水道事業体を取り巻く環境は大きく変化してお り，そのひとつに水道施設の老朽化が挙げられる. 上水道事業の配水管の総延長は約 $596,777 \mathrm{~km}$ であ り，そのうち，約 $8.2 \%$ が布設されてから 40 年を超 えている ${ }^{1)}$. 高度経済成長期に多くの配水管が布設 されたことや管路更新率がのきなみ $1 \%$ 未満である ことから，今後ますます老朽管路が増加し腐食によ る漏水や管路破損事故等が危惧されている2).

日本の総人口は 2060 年には 8,674 万人となり 2010 年に比べて給水人口は約 $1 / 3$ 減少すると予想さ れている ${ }^{3)}$ 。また, 一人一日当たりの生活用水使用 量は 1998 年をピークに緩やかに減少傾向にあり, 理 由の一つに節水機器の普及が指摘されており ${ }^{4)}$, 今 後もその傾向は続くとされている5 . 以上のことか ら, 人口減少と節水機器の普及などで長期的に水需 要が減少し, 現状の管網システムのままでは配水管 内の流速が低下し管内水質劣化が懸念される.

水質劣化の一つに濁質等の堆積が挙げられ, 細菌 の増殖を活発化すること, 消毒効果を低下させるこ と ${ }^{6)}$, 濁水発生リスクを増大させる可能性があるこ となどを踏まえれば，今後如何にして配水管内にお
ける濁質を管理していくかが重要といえる.

一方, オランダでは配水管内で濁質を堆積させな い配水管網が導入されてきた，具体的には，基幹管 路以外の管網を枝状管路化し，かつ小口径管路を布 設することで，単一方向で定期的に大きな流速を発 生させて, 低流速時に堆積した濁質を流し出す配水 管網である ${ }^{7,8)}$. 水需要が減少する状況で安全な水供 給を維持するには，オランダで採用されている配水 管網の設計方法を今後の日本においても検討する意 義があるといえよう。

一方で，日本でオランダのような配水管網を導入

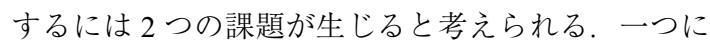
は, 我が国は震災多発国であり管網システムに対し て耐震機能の確保が必要とされ ${ }^{9)}$, 実際に管路のブ ロック化, ループ化等の管路設計手法が取り入れら れている ${ }^{10)}$ ，オランダにおける配水管網の設計手法 で, 震災時に一定水準の給水が継続可能かどうかに ついて検討することが必須である。また，消火栓が 日本の人工水利, すなわち消火栓, 防火水槽, プール 等の保有数の約 $77 \%{ }^{11)}$ を占めており, 現在の配水シ ステムに扔ける消火栓が消防水利の大半を担ってお り, 基幹管路以外の管路の口径の選択には, 消火機 能確保が縮径の制約条件とされている ${ }^{12)}$ 。すなわ 


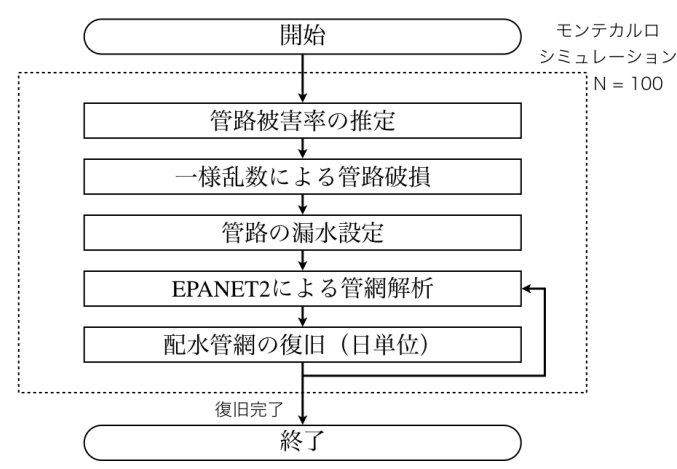

図-1 耐震機能の評価フロー

ち，小口径管路の導入にあたっては，配水管網の消 火用水を確保することができるかについて検討する ことが求められる.

以上のことから, 本研究では「流速により濁質を 堆積させない管路機能」という自己洗浄機能と「地 震時における配水管網の給水能力」という耐震機能, および「配水管網の有する消火用水確保機能」とい う消火機能の 3 つに着目し, 今後の水需要減少社会 に扔ける管網システムのあり方について検討するこ とを目的とする。具体的には，神戸市の実管網を対 象とした管網解析を行い，3つの管路機能の観点か ら管路の縮径と基幹管路以外の枝状化を行った場合 の評価を行う.

\section{2. 解析方法}

本研究では管網解析ソフトとして EPANET 2 を用 いた，流速公式は Hazen-Williams 式，流速係数は 110 とした。な㧍管網システムの再構築手法や耐震 管路の導入については取り扱わないものとする.

\section{（1）評価指標}

\section{a) 自己洗浄機能}

本研究では，管内で濁質が定期的に大きな流速に より流出して濁水が生じない管路機能を自己洗浄機 能と定義する。既往研究より, 2 日に 1 回管内最大 流速が $0.20 \sim 0.25 \mathrm{~m} / \mathrm{s}$ 以上となれば，その管路は清 浄な状態を保てるとされている ${ }^{13)}$ 。そこで本研究で は，1 日に 1 回でも管内流速が $0.20 \mathrm{~m} / \mathrm{s}$ 以上となる 管路については自己洗浄機能を持つとし，管内流速 が $0.20 \mathrm{~m} / \mathrm{s}$ 以下の管路については自己洗浄機能を持 たない，と定義した，具体的には，対象地域の配水 量の実績データを用いて，1 時間毎に管網解析を行 い，その中で任意の管路の流速が最大となる值を用
いて自己洗浄機能を評価した。自己洗浄機能の評価 指標としては，全管路長に対する流速が $0.20 \mathrm{~m} / \mathrm{s}$ 以 上となる管路長の割合を用いることとする.

b) 消火機能

水需要が一番大きいとき，つまり，時間係数 1.81 として算出した計画時間最大給水量に加えて，管路 同士の交点である節点から所定の消火用水量を取り 出して管網解析を行い負圧が発生しなければその節 点で消火栓が使用できると仮定する。任意の管路の 両端の節点で消火栓が使用できる場合に，その管路 上で消火栓が使用できるものとする，全管路長に対 する消火栓が使用できる管路長の割合を消火機能と 定義する。

\section{c）耐震機能}

配水管網の耐震機能を表す指標として震災被害強 度 $(\% \cdot \text { 日 })^{14)}$ を用いる. 本研究では, 配水可能条件 として水需要点に打いて水圧が $10 \mathrm{~m}$ 以上であるこ ととし，その值より小さい場合は断水状態であると する15)。地震時に断水により配水できない総量を平 常時に扔ける全配水量で除して断水率 $(\%)$ を算出す る。断水率を日単位で算出し，それらを震災復旧に 至るまで累計した值を震災被害強度と定義する。な お時間係数は 1 を用いる。

\section{（2）震災時の管網解析}

震災時に打ける配水管網の耐震機能を評価するフ ローチャートを図-1に示す。モンテカルロシミュ レーションの試行回数は 100 回とした。以下に各段 階の詳細を記述する。

\section{a) 管路被害率の推定}

水道技術研究センターの管路被害予測式 ${ }^{16)}$ をい て，各管路の管路被害率を推定する。なお，管路被 害予測におけるハザード情報として，1995 年阪神・ 淡路大震災での表面最大速度（PGV） ${ }^{17)}$ を用いた。

\section{b) 一様乱数による管路破損}

推定した管路被害率と一様乱数によるモンテカル ロ法シミュレーションにより，各管路の破損の有無 を決定する ${ }^{18)}$.

\section{c）管路の漏水設定}

管路破損時の漏水量は管路の破損形態, 破損箇所, 破損の程度，破損箇所の水圧などに依存する。管路 の漏水量推定式を以下に記す。

$$
Q=C \times P \alpha
$$

ここに, $Q$ は漏水量, $C$ は漏水係数, $P$ は水圧, $\alpha$ は管路の破損状態に依存する係数，である。本研究 では, 漏水係数 $C$, ならびに管路破損状態の係数 $\alpha$ 


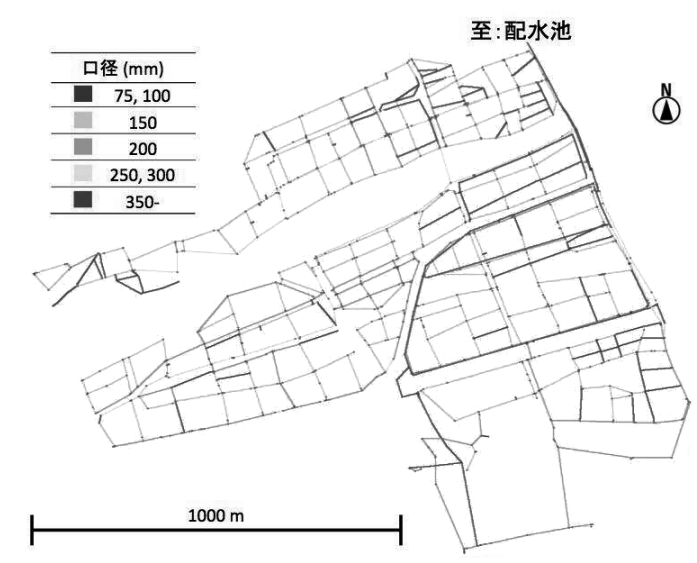

図-2 神戸市灘低層配水区域の口径別配水管網図

は, 1995 年の阪神・淡路大震災での神戸市水道局に おける配水量推移の実績值に基づき推定された值 ${ }^{19)}$ を用いることとし, 漏水係数 $C$ は $2.0 \times 10^{-3} \mathrm{~m}^{2} / \mathrm{s}$, 管路破損状態に係る係数 $\alpha$ は 1 とする.

\section{d）管網解析}

EPANET 2 では破損管路からの漏水が多い場合, 解析結果に負圧を含んで管網解析結果が出力され $る^{20)}$. この場合, 負圧の節点においては, 管路外か ら水が流入しているものと解釈することができ，破 損箇所を含む配水管網における水圧分布, 流量分布, 流速分布を表現することができていないといえる. そこで, 解析結果に負圧が含まれないように負圧が 生じている節点を取り除くこととした，本研究では Cornell 大学が提唱している，最大負圧の節点とそれ に繋がっている管路を管網から除去し管網解析を行 い再び負圧が生じたら同様の手順で負圧が発生しな くなるまで繰り返す方法 ${ }^{21)}$ を採用した。しかしなが ら, この方法では, 配水池から繋がっている管路が 分岐する前の節点で最大負圧が生じた場合，その節 点が取り除かれてしまい配水池から管網に全く水を 供給できなくなる。そこで, 配水池から分岐するま での節点が最大負圧となってもその節点は取り除か ずに，その次に大きな負圧となる節点を除去するこ ととした。 なお，EPANET 2 では配水池からの水供 給は無限であり，管路破損により多大な漏水が生じ ても配水池は枯渇しないものとして管網解析が行わ れる.

\section{e）配水管網の復旧}

管路の復旧は口径や埋設状況等に影響される。本 研究では, 口径の違いにより復旧速度を設定するこ ととし， $\phi 300 \mathrm{~mm}$ 以上の管路に対しては 0.63 件/日とし

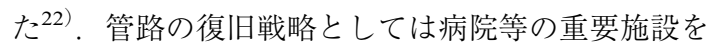
優先することなどが考えられる. 本研究では, 最も 大きな口径を持つ管路から，またそのような管路が 複数存在する場合は配水池から近い管路から復旧す ることとした。 なお，震災時では本来，管路破損部 分をバルブにより配水管網から分離して応急復旧を 実施するが, ここでは分離しない状態で管路の修復 を行うものとした.

\section{（3）解析対象地域}

神戸市水道局東部センターの配水区域内で，神戸 市灘区の市街地に位置し最も大阪湾に近い灘低層配 水池区域を解析対象地域とした。 2013 年時点におけ る配水管網データを用いた。図-2, 表-1に口径別配 水管網図と口径別管路長割合を示す。なお，本稿で は, 灘低層配水池区域と隣接する篠原低層配水池区 域, 熊内低層配水池区域などへの連絡管は除去した. 解析対象地域は, 北側の標高が高く，南側の標高が 低くなっており, 図上から図下の方向への自然流下 方式による配水方式となっている。なお, 本解析対 象地域における 2013 年の一日当たりの配水量実績 值は約 4, $330 \mathrm{~m}^{3} /$ 日である。また， 2013 年時点にお いては, この灘低層配水区域は小ブロックの整備が なされていない地域である。

\section{3. 配水管網の枝状化と縮径}

\section{（1）枝状化}

配水管網を枝状化するにあたり，節点に対する水 需要の割り当てによる影響を把握するため, 以下の 枝状管網 $\mathrm{A}$ と枝状管網 B との 2 通りを設定した。

1） $\phi 300 \mathrm{~mm}$ 以上の管路は基幹管路とみなして枝 状化は行わず， $\phi 250 \mathrm{~mm}$ 以下の管路で基幹管 路とはみなせない配水支管を中心に枝状化す る.

2）原則として現状管網の平常時配水量時（時間係

表-1 神戸市灘低層配水区域の口径別管路長割合

\begin{tabular}{cccccccccc}
\hline \multirow{2}{*}{ 管路延長 $(\mathrm{m})$} & \multicolumn{8}{c}{ 口径別管路延長割合 (\%) } & \multicolumn{1}{c}{ 口径単位 $： \mathrm{~mm}$} \\
& & $\phi 75$ & $\phi 100$ & $\phi 150$ & $\phi 200$ & $\phi 250$ & $\phi 300$ & $\phi 350-$ \\
\hline 42,266 & 1,358 & 0.27 & 14.29 & 43.74 & 20.91 & 0.27 & 10.24 & 10.28 \\
\hline
\end{tabular}




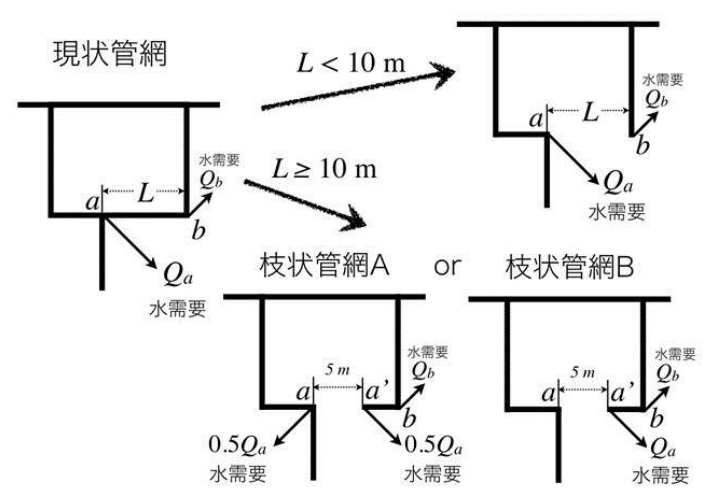

図-3 各節点に対する水需要の配分と管網設定手法

表-2 検討した縮径条件

\begin{tabular}{cc}
\hline CASE & 縮径条件 \\
\hline CASE 1 & なし \\
CASE 2 & $150 \mathrm{~mm} \rightarrow 100 \mathrm{~mm}$ \\
CASE 3 & $150 \mathrm{~mm}, 100 \mathrm{~mm} \rightarrow 75 \mathrm{~mm}$ \\
CASE 4 & $150 \mathrm{~mm}-75 \mathrm{~mm} \rightarrow 50 \mathrm{~mm}$ \\
CASE 5 & $200 \mathrm{~mm}$ 以上を 1 規格小 \\
CASE 6 & CASE 2 + CASE 5 \\
CASE 7 & CASE 3 + CASE 5 \\
CASE 8 & CASE 4 + CASE 5 \\
\hline
\end{tabular}

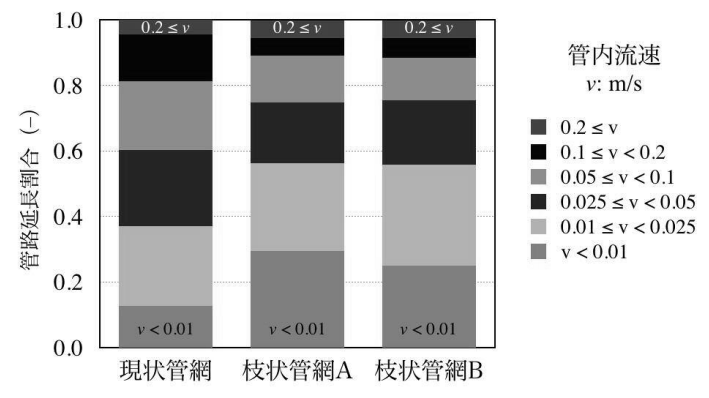

図-4＼cjkstart枝状化による管内流速分布の変化

数 1）に打ける流れ方向に従い, かつ, 配水本管 に近い方から配水できるように枝状化を行う。

3）図-3に示す節点 $a$, 節点 $b$ の管路長 $L$ が $10 \mathrm{~m}$ よりも短い管路を枝状化する場合, 枝状管網 A, 枝状管網 B のいずれにおいてもその管路を除去 する.このとき, 節点 $a$, 節点 $b$ における水需要 $Q_{a}, Q_{b}$ は変えないものとする.

4）管路長 $L$ が $10 \mathrm{~m}$ 以上の管路を枝状化する場合, 節点 $a$ から接続を切り, その管路を $5 \mathrm{~m}$ 短くし, 新たに節点 $a^{\prime}$ を設定する。 そのうえで，枝状管 網 $\mathrm{A}$ では, 水需要 $Q_{a}$ を等分し, 節点 $a, a^{\prime}$ にそ れぞれ $0.5 Q_{a}$ の水需要を割り当てる. 枝状管網 $\mathrm{B}$ では, 節点 $a^{\prime}$ にのみ水需要 $Q_{a}$ を割り当てるも
のとする，なお，枝状管網 A，B のいずれにお いても, 節点 $b$ に扮ける水需要 $Q_{b}$ は枝状化の前 後で変えないものとする. 図-3に以上の設定方 法を示す。

この結果，管路長は約 $41,407 \mathrm{~m}$ となり，管路延長 は現状管網に比べて約 $98 \%$ となった。

\section{（2）縮径}

表-2に示すように配水管網の縮径を行った. CASE 2, CASE 3 は主に $\phi 150 \mathrm{~mm}$ の管路を縮径して おり, 水圧と水量が十分確保できる場合のみ消火用 水が確保できる ${ }^{12,23)}$. CASE 4 では管路を $\phi 50 \mathrm{~mm}$ まで縮径しており，この管路上には消火栓が設置で きず, 消火栓以外の消防水利が必要な CASE といえ る. CASE 5 では比較的口径の大きい管路を一規格 縮径した. CASE 6〜CASE 8 では比較的口径の小さ い管路と大きい管路を同時に縮径した CASEであ る。

\section{4. 解析結果と考察}

\section{（1）配水管網の枝状化}

図-4に現状管網と枝状管網における管内流速の変 化を示す．現状管網では自己洗浄機能を持つ管路の 割合が $4.4 \%$ であるが, 枝状管網 A, B では共に $5.6 \%$ となり，枝状管網によって約 $1.2 \%$ の管路が自 己洗浄機能を持つようになった。一方で, $0.01 \mathrm{~m} / \mathrm{s}$ より小さい流速である管路長割合が現状管網，枝状 管網 A，B それぞれ $12.8 \% ， 29.4 \% ， 24.9 \%$ であり， 枝状管網 A, B ともに現状管網に比べて約 2 倍に増 加した，小口径の配水支管は，流入点から水需要の ある節点までの管路延長が長くなり (図-3参照)，管 内流速 $0.01 \mathrm{~m} / \mathrm{s}$ 未満の管路延長割合が増大したもの と推察できる，また，水需要が少ない場合に，行き 止まり管に近い状況になる。一方, 口径 $300 \mathrm{~mm}$ 以 上の配水本管における管内流速が増加した.

Blokker ら ${ }^{24)}$ はバルブを閉じることで単一方向か つ大きな流速を作り出すことを実管網で試みた。こ こではバルブを閉じて管網の基幹管路以外の部分を 枝状化していることと同じであり，本稿と類似した 試みである。その結果，流速 $0.20 \mathrm{~m} / \mathrm{s}$ 以上の管路長 割合が約 32\% 増加したと報告している。しかし，依 然として約 $63 \%$ の管路が自己洗浄機能を持たず，単 一方向流れを作り出すだけでは不十分で縮径が必要 であると指摘している。今回の解析結果は, Blokker らの結果と比較して自己洗浄機能を持つようになっ た管路長割合が約 $1.2 \%$ と小さい。このことは, 
表-3 現状管網, 枝状管網の消火機能評価結果

同時使用消火栓数 : 2 栓

\begin{tabular}{|c|c|c|c|}
\hline & 現状管網 & 枝状管網 A & 枝状管網 B \\
\hline $\begin{array}{l}\text { 消火栓設置可 } \\
\text { 能管路長割合 }\end{array}$ & $100 \%$ & $99 \%$ & $99 \%$ \\
\hline \multicolumn{4}{|c|}{ 同時使用消火栓数 : 5 栓 } \\
\hline & 現状管網 & 枝状管網 A & 枝状管網 B \\
\hline $\begin{array}{l}\text { 消火栓設置可 } \\
\text { 能管路長割合 }\end{array}$ & $99 \%$ & $63 \%$ & $63 \%$ \\
\hline
\end{tabular}

表-4 現状管網, 枝状管網の耐震機能評価結果

\begin{tabular}{cccc}
\hline & 現状管網 & 枝状管網 A & 枝状管網 B \\
\hline $\begin{array}{c}\text { 震災被害強度 } \\
(\% \cdot 日)\end{array}$ & $383 \% \cdot$ 日 & $338 \% \cdot 日$ & $358 \% \cdot 日$ \\
\hline
\end{tabular}

Blokker らの対象としている管路の流速が最初から 比較的大きかった可能性があること, Blokker らは管 網の枝状化を行う際に管路の流向にこだわらずに, 可能な限り流速が増加するような管網の設計を行っ ていたことなどが考えられる。しかしながら，本研 究では, バルブ操作については取り扱っておらず, かつ，本稿での枝状化においては，現状管網におけ る管内の流れ方向を確保する条件下で行ったことか ら，必ずしも小口径の配水支管についても管内流速 を十分に増大させる条件での枝状化とはいえないと 考えられる。

現状管網，ならびに枝状管網における消火機能の 変化を表-3に示す。解析対象地域の神戸市において は，水道局と消防局との協議により，配水区域によ り同時使用消火栓数が定められている25). すなわ ち, 配水池 ·減圧槽容量が $200 \mathrm{~m}^{3}$ 以下の区域及び現 状管網における放水可能栓数が 2 栓の区域から, 低 層 - 中層配水区域等大規模な配水区域のうち現状管 網における放水可能栓数が 5 栓以上の区域まで定め られている。 これを参考として，本稿では同時使用 栓数を 2 栓と 5 栓との 2 通りで評価した.

その結果, 消火機能は, 2 栓同時使用時にはいずれ の管網もほぼすべての管路で消火機能が確保でき た.しかしながら，5栓同時開栓時には現状管網で はほぼ消火機能が維持されているが, 枝状管網では, 消火機能が $63 \%$ と減少し, 現状管網よりも $36 \%$ 低下 した。 これは，枝状管網では同時使用消火栓数が増 加した場合に，一部の管路に流量が集中しやすく， その管路上で損失水頭が大きくなったためと考えら れる。 また, 同時使用消火栓数次第では, 枝状管網 でも現状管網と同程度に消火機能を確保できること が分かった。
一方，枝状管網 A, B ともに消火機能は同じであっ た。これは，消火用水量が平常時の時間最大時にお ける水使用量よりも大きいためと考えられる.

各管網における耐震機能評価結果を表-4に示す. これより，現状管網に比べて，枝状管網 A, Bにおい て震災被害強度がそれぞれ $11.7 \%, 6.5 \%$ 減少して いる。震災被害強度は, 断水率の積分值であること から，地震ハザードによる被害の程度のみならず， 回復力についても評価するものである。枝状管網に おいては，現状管網と比較して，200 mm，150 mmの 小口径の管路延長が $2 \%$ 小さいことから，管路被害 件数が $2 \%$ 程度少なく推定されている. 枝状管網に ついては，その形状から直後からの被害管路の復旧 により断水率が減少している。しかしながら，現状 管網については，管路の復旧過程が口径の大きな管 路, かつ上流側から復旧を行う条件ではあるものの, 直後においては復旧によりすぐに断水率が減少する のではなく，ある程度の復旧が進んだ後に断水率が 減少していく傾向がみられた。すなわち，枝状管網 においては，災害直後からある一定の回復力が見込 まれるが，現状管網においては，被害管路の復旧戦 略により，その回復力が左右されると推察できよう.

\section{（2）配水管網の枝状化と縮径}

図-5に縮径時における自己洗浄機能の変化を示 す。現状管網での自己洗浄機能評価結果より, CASE 3 と CASE 4 とを比べると自己洗浄機能を有する管 路延長はそれぞれ $7.8 \%$ と $15.6 \%$ であり，より小口 径の $50 \mathrm{~mm}$ での縮径を行ったCASE 4 の方が約 $8 \%$ 自己洗浄機能が大きくなっている。，一方，枝状管網 A, B においては, CASE 2 から CASE3, CASE 3 から CASE 4 と口径を小さくするにつれ, 自己洗浄機能が 約 6〜8\% 増加する傾向がみられた。すなわち，枝状 管網は，配水支管のうち $150 \mathrm{~mm}$ 以下の管路を縮径 することにより，現状管網と比較して，管内流速の 増大がより効果的にみられ, 自己洗浄機能の確保に は有利といえる。配水本管を縮径した CASE 5〜CASE 8 においては，枝状管網については，配水 支管のみを縮径した CASE 2〜CASE 4 とほぼ同程度 の自己洗浄機能確保となっている。一方, 現状管網 においては，150 mm 以下の配水支管のみを縮径した CASE 2〜CASE 4 と比較して, より管内流速が増大 しており，枝状管網と同程度の自己洗浄機能を確保 することができている。したがって，自己洗浄機能 確保という観点からは，現状管網については，末端 の配水支管のみの縮径ではその効果が十分にみられ ないが，配水本管の縮径と組み合わせることで，効 果的な機能確保が可能であるといえ，枝状管網につ 


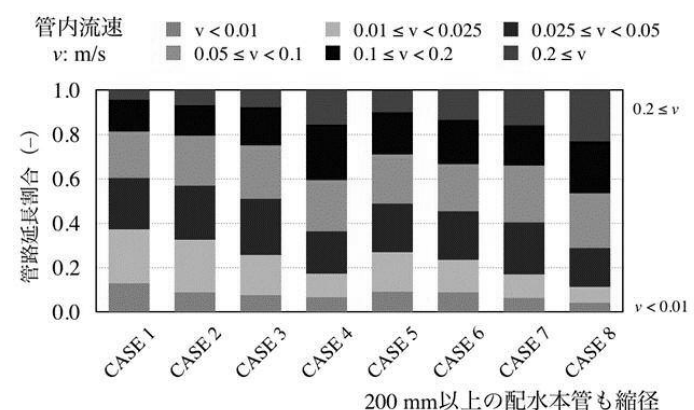

図-5（a）縮経時における管内流速分布変化（現状管網）

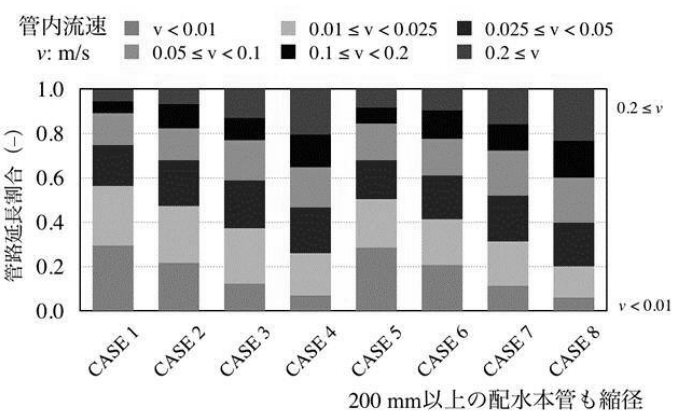

図-5（b） 縮経時における管内流速分布変化（枝状管網 A)

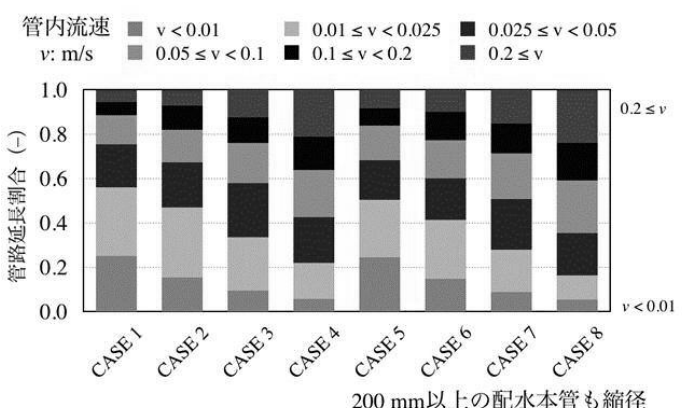

図-5（c）縮経時における管内流速分布変化（枝状管網 B)

いては，現状管網よりも配水支管の縮径によって自 己洗浄機能が効果的に確保できるといえた.

枝状管網 A と枝状管網 B とでは, 自己洗浄機能を 有する管路延長割合は, CASE 1, CASE4, CASE 8 で それぞれ $0.06,0.06,0.21,0.21,0.24,0.24$ であ る。図-3に示したように，枝状管網 B は，枝状管網 $\mathrm{A}$ と比べてより管路末端に水需要を割り当てるもの であるが, 自己洗浄機能確保の観点からは, 管網の 枝状化に伴う水需要の配分方法の影響はないといえ た。

表-5に縮径時における消火機能の変化を示す。表 -3より枝状管網 A, B の消火機能が同じであったた め, ここでは，縮径時においても枝状管網 A, B で消
表-5 各管網の消火機能評価結果

\begin{tabular}{lcccc}
\hline & \multicolumn{3}{c}{ 消火栓設置可能管路延長割合 (\%) } \\
\cline { 2 - 5 } & $\begin{array}{c}\text { 同時使用消火栓数 2 栓 } \\
\text { 現状管網 }\end{array}$ & 枝状管網 A & 現状管網 & 枝状管網 A \\
\hline CASE 1 & $100 \%$ & $99 \%$ & $99 \%$ & $63 \%$ \\
CASE 2 & $100 \%$ & $71 \%$ & $94 \%$ & $36 \%$ \\
CASE 3 & $98 \%$ & $37 \%$ & $54 \%$ & $35 \%$ \\
CASE 4 & $47 \%$ & $35 \%$ & $42 \%$ & $34 \%$ \\
CASE 5 & $100 \%$ & $67 \%$ & $92 \%$ & $30 \%$ \\
CASE 6 & $97 \%$ & $37 \%$ & $48 \%$ & $29 \%$ \\
CASE 7 & $97 \%$ & $37 \%$ & $48 \%$ & $29 \%$ \\
CASE 8 & $46 \%$ & $35 \%$ & $39 \%$ & $25 \%$ \\
\hline
\end{tabular}

火機能が同じであるとみなすこととし，枝状管網 A のみの結果を示す．同時使用消火栓数 2 栓の場合の 消火機能は, 現状管網では CASE 4 で 47\%, 枝状管網 A では CASE 3 で37\%であり大きく低下した，現状 管網の CASE 4 と枝状管網 A の CASE 3 は自己洗浄 機能が大きく向上している，すなわち，同時使用消 火栓数 2 栓を想定した場合, 枝状管網, 現状管網と もに, CASE 1 から CASE 4, CASE 5 から CASE 8 へ の縮径に伴い, 自己洗浄機能が増大する一方で, 消 火機能確保が低減することとなり，これらはトレー ドオフ関係にあると指摘できよう。

同時使用消火栓数 5 栓の場合の消火機能は, 枝状 管網 A では CASE 1 以外は消火機能が $50 \%$ 以下であ ることから，枝状管網において縮径を行った場合に は, 別の消防水利を設置する必要があるといえる. また, 現状管網の消火機能は CASE 1, 2, 5, 6 では $90 \%$ 以上を確保しているが CASE 3, 4, 7, 8 では約 40\%〜60\% 低下している. したがって， $75 \mathrm{~mm}$ ，ある いは $50 \mathrm{~mm}$ での縮径を行った場合には，現状管網に ついても当該地域における消火機能の確保について 検討することが求められる.

表-6に縮径時における耐震機能の変化を示す. 配 水管網を縮径することで, 多くの CASE で震災被害 強度が大きくなった。これは，管路を縮径すること で管路の破損確率が大きくなり，管路の破損件数が 大きくなったためである. CASE 4, 5 では現状管網 の方が枝状管網よりも震災被害強度が小さく耐震性 があった。 それら以外の 5 つの CASEでは枝状管網 の方が耐震性が震災被害強度が小さく耐震性があっ た。村田ら ${ }^{26)}$ は配水支管が網目状であっても配水支 管の形状によっては震災時の配水管内水圧の低下が 局所化できるブロック化管網とできない非ブロック 化管網があると推定している。この灘低層配水池区 
表-6 各管網の耐震機能評価結果

\begin{tabular}{|c|c|c|c|}
\hline & \multicolumn{3}{|c|}{ 震㷋被害強度（\%・日） } \\
\hline & 現状管網 & 枝状管網 A & 枝状管網 B \\
\hline CASE 1 & 383 & 338 & 358 \\
\hline CASE 2 & 466 & 412 & 317 \\
\hline CASE 3 & \multicolumn{3}{|c|}{ CASE 2 と同様のため評価せず } \\
\hline CASE 4 & 1466 & 1086 & 1135 \\
\hline CASE 5 & 1206 & 1227 & 1358 \\
\hline CASE 6 & 743 & 783 & 754 \\
\hline CASE 7 & 773 & 673 & 638 \\
\hline CASE 8 & 1862 & 1435 & 1488 \\
\hline
\end{tabular}

域はブロック化整備がなされていない.したがっ て，管路破損箇所付近の配水管水圧の低下が局所化 されなかった可能性があり，また管路被害件数が枝 状管網よりも多かったために, 多くの CASEで現状 管網の方が枝状管網よりも震災被害強度が大きく なったと考えられる。また, 現状管網, 枝状管網と もに自己洗浄機能が大きく増加したCASE と震災被 害強度が大きくなった CASE はある程度一致してい る。したがって, 震災被害強度が増大するというこ とは，被害の程度が大きくなる，あるいは回復力が 小さくなることと同義であることから, 管網の耐震 機能が低減するといえる。これらのことから，本稿 で検討した配水管網の縮径においては, 耐震機能と 自己洗浄機能はトレードオフ関係にある, といえよ う。

\section{5. 結言}

本稿では, 管網の自己洗浄機能, 耐震機能および 消火機能という 3 つの機能から, 水需要減少社会に むけた管路形状と縮径による管網システムのあり方 について検討した，以下に得られた知見を示す。

1）現状管網を枝状管網とすることにより，300 mm 以上の配水本管に打ける管内流速が増大し，管 網システムにおける自己洗浄機能は微増する傾 向が認められた，消火機能については，同時使 用消火栓数 5 栓というより厳しい条件下では現 状管網と比べて大きく低下した。

2）耐震機能では，震災被害強度が現状管網よりも 約 $10 \%$ 程度低減し，枝状管網においては災害初 動時からの断水率低減, すなわち一定の回復力 を確保することができた。 また，現状管網にお いては, 被害管路の復旧戦略により, その回復
力が左右されることを指摘した

3）管路の縮径について検討した結果, 現状管網に ついては，末端の配水支管のみの縮径ではその 効果が十分にみられないが, 配水本管の縮径と 組み合わせることで, 効果的な自己洗浄機能の 確保が可能といえた。 また, 枝状管網について は，配水支管の縮径によって自己洗浄機能が効 果的に確保できるといえた。

4）管網の枝状化手法において, 自己洗浄機能確保 の観点からは, 枝状化に伴う水需要の配分方法 の影響はないといえた

5）管路の縮径と枝状化との検討結果から, 縮径に より自己洗浄機能が増大する一方で, 消火機能 確保が低減することとなり, 自己洗浄機能確保 と消火機能確保がトレードオフ関係にあると指 摘できた。また, 縮径により自己洗浄機能が増 大するとともに震災被害強度も増加傾向がみら れ，配水管網の縮径においては，自己洗浄機能 と耐震機能とがトレードオフ関係にある, と示 しえた。

謝辞：神戸市水道局には配水管網のデー夕を提供し て頂き，また種々の助言を頂いた。ここに謝意を示 す.

\section{参考文献}

1）日本水道協会：水道統計施設・業務編， 2012 .

2）荒井康裕, 小泉明, 稲員とよの, 渡辺晴彦, 國實誉治, 林光夫：送配水管路事故の実態調査アンケートデー夕 による故障率曲線の推定方法, 環境システム研究論文 集, Vol. 36, pp. 125-130, 2008.

3）国立社会保障 - 人口問題研究所：人口統計資料 2013 年版, 2013 .

4) 国土交通省土地 - 水資源局水資源部：平成 20 年版日 本の水資源について，2008.

5）山田淳, 吉村敬介, 山川幹人：ライフスタイルの変化 による住宅内での水利用構造と環境負荷への影響予 測, 第 32 回環境システム研究論文発表会講演集, pp. 343-348, 2004.

6) WHO: Guidelines for drinking-water quality, fourth edition, 2011.

7) van der Kooij, D. and van der Wielen, P. W. : Microbial Growth in Drinking-Water Supplies, 2014.

8) Boomen, M. van den, Mazijk, A. van, and Beuken, R. H. S. : First evaluation of new design concepts for self-cleaning distribution network, Journal of Water Supply: Research and Technology-AQUA, Vol. 53, No. 1, pp. 43-50, 2004.

9）日本水道協会 : 水道施設耐震工法指針解説 2009 年版 I 
総論, 2009.

10）厚生省：配水ブロック整備手法に関する調査，1993.

11）総務省消防庁：平成 26 年版消防白書, 2015 .

12）今田俊彦, 小棚木修, 山田良作 : 配水ブロックシステ ムにおける配水本管・支管の経済的口径の決定手法, 水道協会雑誌, Vol. 71, No. 10, pp. 12-26, 2002.

13) Blokker, E., Vreeburg, J., Schaap, P. and van Dijk, J. : The self-cleaning velocity in practice, Water Distribu-tion Systems Analysis 2010, 2010.

14）汐崎剛, 増田貴則, 住友恒, 伊藤禎彦, 小倉晉, 松下 眞: 管路および配水管網の地震被害対策, 第 4 回 水道 管路国際シンポジウム講演集, pp. 137-145, 1997.

15）和田昌寛, 山田武史, 平山修久, 伊藤禎彦 : 管路再構 築における管路の自己洗浄性と耐震性の機能確保に 関する検討, 土木学会論文集 G (環境), Vol. 70, No. 6, pp. II_309-II_317, 2013.

16）水道技術研究センター：地震による管路被害予測の確 立に向けた研究報告書, 2013 .

17) Hirayama, N., Yamada, T., Wada, M. , Itoh, S., and Davis, C. A. : Evaluation of fire protection capacity in disasters based on disaster resilience curve, 9th Japan-US-Taiwan Workshop on Water Supply System Seismic Practices 2015, CD-ROM, 2015.

18）山田武史, 和田昌寛, 平山修久, 伊藤禎彦 : 災害レジ リエンス曲線による配水管網の消火機能評価手法の 構築, 土木学会論文集 $\mathrm{G}$ (環境), Vol. 70, No. 7, pp. III_111-III_118, 2014.

19) Sakaki, K., Matsuda, Y., Hirayama, N., and Itoh, S. : Development of comprehensive evaluation procedure for anti-seismic strategies: evaluating Kobe City's earthquake resistance improvement pan from the customer's viewpoint, Journal of Water Supply: Research and Technology-AQUA, Vol. 63, No. 2, pp. 139-145, 2014.

20) Saleh, S. H. and Tanyimboh, T. T. : Coupled topology and pipe size optimization of water distribution systems, Water resources management, Vol. 27, No. 14, pp. 4795-4814, 2013.

21) Cornell University: GIRAFFE user's manual, 2008.

22）榊恭平, 田中孝昌, 松田康孝, 平山修久, 伊藤禎彦 : 水道事業体における耐震化施策効果の統合的評価手 法の開発, 環境衛生工学研究, Vol. 27, No. 3, pp. 28-31, 2013 .

23）日本水道協会：水道施設設計指針 2012, 2012.

24) Blokker, E. J. M., Schaap, P. G. and Vreeburg, J. H. G. : Comparing the fouling rate of a drinking water distribution system in two different configurations, CCWI2011 Urban Water Management: Challenges and Opportunities, D. Savic, Z. Kapelan, and D. Butler, eds., Centre for Water Systems, University of Exeter, Exeter, pp. 583-588, 2011.

25）松岡秀明, 神崎淳, 大上淳也, 七條忠晃, 林一平, 牛 尾亮太 : 小規模配水区域における消火栓同時使用栓数 の検討, 平成 27 年度全国会議（水道研究発表会）講演 集, pp. 86-87, 2015.

26）村田幸一, 宮島昌克：水道管網特性による耐震性評価 とその投資効果分析について, 土木学会地震工学論文 集, Vol. 28, P67: 1-8, 2005.

(2016. 5. 26 受付)

\title{
A STUDY ON REDESIGNING OF WATER DISTRIBUTION SYSTEM TOWARDS A DEPOPULATION SOCIETY
}

\author{
Nagahisa HIRAYAMA, Takefumi YAMADA, Shinya ECHIGO and Sadahiko ITOH
}

Water utilities in Japan should redeign their water distribution system considering the decrease of water demande and rebuilt their deteriorated distirbution pipes. The purpose of this study is to examine the concept of water distribution system redesigning from the viewpoints of self-cleaning function, fire protection function, and earthquake disaster resilience. In this study, a procedure of downsizeing and redesigning of water distribution network applied to the actual water distirbution system in Kobe City, the performance of fuctions in seld-cleaning, fire protetion, and earthquake disaster resilience were evaluated. As a result, a tradeoff between self-cleaning function and fire protection fuction was pointed out. In addition, it was indicated that the balance between earthquake disaster resilience and self-cleaning fucntion is requied for water system in Japan. 